\title{
Bizalom és megbízhatóság - egy módosított ismételt bizalomjáték eredménuei*
}

Gelei Andrea,

a Budapesti Corvinus Egyetem egyetemi tanára

E-mail: andrea.gelei@unicorvinus.hu

\section{Dobos Imre,}

a Budapesti Müszaki és Gazdaságtudományi Egyetem egyetemi tanára

E-mail: dobos@kgt.bme.hu

\section{Dudás Levente,}

a Budapesti Corvinus Egyetem PhD-hallgatója

E-mail: lev.dudas@gmail.com
A szerzők egy általuk kidolgozott ismétlődő bizalomjátékot mutatnak be és vizsgálnak empirikusan. A játék megkülönbözteti a bizalom, a bizalomra méltóság és a megbízhatóság fogalmait. Mind a bizalom, mind a bizalomra méltóság a játék során a szereplők cselekvéseiben mutatkozik meg, ezáltal értelmezhető. A megbízhatóság ugyanakkor állomány jellegü fogalom, a bizalmat adó fél észlelése, várakozása arra vonatkozóan, mennyire lesz bizalomra méltó a bizalmat kapó fél.

A szerzők adatfelvétele az ismételt bizalomjátékok csoportjába tartozik. Egy játék 10 körből állt. A játék során anonim párokat alakítottak ki, és közvetlenül mérték a megbízhatóság észlelt szintjeit. Jelentős különbség a korábbi ismételt bizalomjátékokhoz képest, hogy a játékkörökben a megosztható összeg kumulálódott. Mindez a valós üzleti kapcsolatokhoz hasonlító interaktív szituációt teremtett. Ezen kívül speciális kifizetőfüggvényt (hasznosságfüggvényt) alkalmaztak, melynek révén a játékosok között együttmüködve versengő kapcsolat jött létre. A szerzők a bizalomjáték e speciális formáját használták arra, hogy teszteljék hipotézisüket, mely szerint a felek között kialakuló megbízhatóság a kapcsolatban zajló események (bizalom és bizalomra méltóság) következményeként változik, alakul.

TÁRGYSZÓ:

Ismételt bizalomjáték.

Bizalom, bizalomra méltóság, megbízhatóság.

Regresszióelemzés.

DOI: $10.20311 /$ stat2018.08-09.hu0769

* A szerzök kutatásait az OTKA K-115542. számú pályázat támogatta. A szerzök köszönik a két anonim bíráló hasznos megjegyzéseit. 
A gazdálkodástudományban az elmúlt évtizedekben paradigmaváltás volt. A hagyományos, vállalatközpontú elemzéseket egyre erőteljesebben egészítik ki a vállalatok közötti kapcsolatokat és azok rendszereinek vizsgálatát középpontba állító kutatások (Håkansson-Snehota [1989], Johanson-Mattsson [2015]). Az üzleti kapcsolatnak, a bennük végbemenő jelenségeknek és azok hatásainak mélyebb megértése az elmúlt évtizedek egyik kiemelt kutatási iránya volt (Samiee-Walters [2003], Pilbeam-Alvarez-Wilson [2012], Hohenthal-Johanson-Johanson [2014]). Az üzleti kapcsolat jelentéstartalmának meghatározása, az egyes kapcsolati jelenségek megértése nagy kihívás. Ilyen összetett és fontos kapcsolati jellemzö az együttmüködő partnerek közötti bizalom (Blomqvist [1997], Hámori [2004]) is.

Munkánkban a tranzakciós költségek elméletéhez kötődő irányítási mechanizmus értelmezését (Williamson [1979]) tekintjük kiindulópontnak. E szerint az irányítási mechanizmusok olyan eszközök, melyeket a cégek szervezetközi kapcsolataikban azért alkalmaznak, hogy összehangolják tevékenységüket és ezzel minimalizálják kitettségüket az opportunista viselkedésnek (Jap-Ganesan [2000]). Három alapvető irányítási mechanizmust különíthetünk el: 1 . a piaci koordináció szerződéseken keresztül irányít; 2. a szervezeti vagy hierarchikus koordináció a tulajdonjogon és ezek alapján az utasítási jogon alapuló biztosítékokat használja; 3. az ún. kapcsolati koordináció esetében pedig az együttmüködő felek közötti társas jellemzők (például a bizalom szintje) az eszközei a kapcsolatban zajló események irányításának (Wang$X u-$ Weitz [2008]).

A bizalomnak mint irányítási eszköznek a kockázatos, az opportunista viselkedés számára lehetőséget teremtő helyzetekben van jelentősége (Das-Teng [2004]). Maga a bizalom a hagyományos értelmezésben nem más, mint az egyénnek az a meggyőződése, hogy partnere nem él vissza sebezhetőségével (Korczynski [2000]). Ez a bizalom ún. hit- (vagy meggyőződés-) alapú felfogása (Kumar [1996]). Ezt képviselik Morgan és Hunt [1994] is, akik szerint a bizalom nem más, mint egy kapcsolatban a bizalmat adó fél hite arra vonatkozóan, hogy az üzleti csere során a másik (a bizalmat kapó) fél a bizalmat adó sebezhetöségét nem fogja kihasználni. Mayer-Davis-Schoorman [1995] a szervezeti magatartás tudományterületén végzett kutatásaikban ugyanakkor rámutatnak a bizalom (trust) és a bizalomra méltóság vagy megbízhatóság (trustworthiness) fogalmai között meglevő különbségre. Hangsúlyozzák, hogy a bizalomnak az előzőkben ismertetett, ún. hiten, meggyőződésen alapuló értelmezése öszszemossa ezt a két fogalmat, azokat szinonimaként használja. Véleményük szerint ez az értelmezés - tehát a bizalmat adó fél (trustor) észlelése arra vonatkozóan, hogy mennyire lesz bizalomra méltó a másik, a bizalmat kapó (trustee) - a bizalomra mél- 
tóság, röviden megbízhatóság. Morgan és Hunt - de más szerzők, mint például Barney-Hansen [1994], Mayer-Davis-Schoorman [1995] - felfogásában ugyanakkor a bizalom mást jelent: cselekvési hajlandóság, a bizalmat adó fél hajlandósága arra, hogy adott partnerével kapcsolatuk során kockázatos magatartást vállaljon fel, olyat, melynek következtében növekszik sebezhetősége, kitettsége a partner opportunista viselkedésének. A bizalomra méltóság tehát nem más, mint a bizalmat adó fél észlelése, várakozása a bizalmat kapó félre vonatkozóan. Másik oldalról megközelítve ez azt is jelenti, hogy a megbízhatóság a bizalmat kapó fél jellemzője. Ezzel szemben a bizalom a bizalmat adó fél adott (kockázatos) tranzakcióban megfigyelhető konkrét viselkedésével kapcsolatos. Ebben a megközelítésben a bizalomra méltóság gyakorlatilag állományjellegü (stock) kategória, az adott személy bizalmi készlete, mely aztán konkrét kockázati szituációkban értékelhető, és adott esetben a cselekvés irányítási eszközévé válhat. Amennyiben a bizalomra méltóság, azaz a megbízhatóság észlelt szintje elegendő, akkor az adott kockázatos kapcsolati szituációban megmutatkozhat a bizalom, maga a kockázatos cselekvés mint folyamatjellegü (flow) kategória. A megbízhatóság észlelt szintje tehát kritikus jellemzője a kapcsolatnak, annak állománya ténylegesen a kapcsolati szituáció irányítási eszközévé válhat, és jó esetben elvezethet a bizalomhoz. Ennek a megbízhatóságnak a változását és a változások okait vizsgáljuk tanulmányunkban. Kidolgoztuk a klasszikus bizalomjáték (Berg-DickhautMcCabe [1995]) módosított változatát, mely a korábbi ismételt játékoktól több ponton is eltér. Alapkérdésünk szempontjából kiemelten fontos, hogy a játékosok megbízhatóságának mérését beépítettük a játékba, mégpedig oly módon, hogy annak alakulását csak a szereplők játékban mutatott aktuális döntései befolyásolták, tehát a játékosoknak semmilyen előzetes információjuk nem volt játékostársukról, például annak reputációjáról (Boero et al. [2009]).

Ezen kívül sajátosság, hogy míg a korábbi ismételt játékokban az egyes körök a felosztható pénzösszeg tekintetében függetlenek voltak egymástól (Bohnet-Huck [2004], Boero et al. [2009]), ebben a játékban a megosztható összeg a körök során kumulálódott. A játéknak ez a tulajdonsága megítélésünk szerint sokkal inkább hasonlít tartós üzleti kapcsolatokban zajló eseményekhez, mint annak feltételezése, hogy a két fél közötti tranzakciótípusok egyszerüen ismétlődnek. Az üzleti kapcsolatok kutatásának egyik meghatározó szakmai közössége, az ún. IMP-Group ${ }^{1}$ (Industrial Marketing and Purchasing Group - Ipari Marketing és Beszerzési Csoport) kutatói a kapcsolatban zajló folyamatok megnevezésére a tranzakció helyett az interakció kifejezés használatát javasolják (Ford et al. [2008]). Ez az interakció hosszabb időtávot, több eseményt felölelő folyamat, mely során a felek alkalmazkodnak egymáshoz, közöttük kölcsönös befektetésekkel járó adaptáció zajlik, hiszen a közös célok, az üzleti siker elérése érdekében együtt kell müködniük egymással. Ezek az üzleti kapcsolatok

\footnotetext{
${ }^{1}$ www. impgroup.org
} 
ugyanakkor nem örökkévalók, többéves partnerség után is fel tudnak bomlani. A kölcsönös egymásrautaltság megszűnése pedig teret engedhet az opportunista viselkedésnek. Gondoljunk például egy autóipari beszállítói szerződésre, ahol a felek 3 évre elköteleződnek egymás iránt, de ezen időszak végén az addig együttműködő attitűdöt a versengö válthatja fel. Alapvetően egy ilyen együttmüködve versengő (competitive) kapcsolati szituáció alakult ki játékunk során is a felek között. ${ }^{2}$

Speciális kifizetőfüggvényt alkalmaztunk, mely a játék során alapvetően támogatja a felek közötti együttmüködve versengést, s melynek következtében - várakozásunk szerint - a játék összállapotának Pareto-optimuma és a játékosok egyéni stratégiáinak Nash-egyensúlya - azaz az az állapota, amelyet a játékosok nem akarnak megváltoztatni - azonos. A bizalomjáték e speciális formáját használjuk munkánkban arra, hogy vizsgáljuk alapkérdésünket, a bizalomra méltóság, azaz a megbízhatóság hogyan változik a kapcsolatban zajló események függvényében. A megbízhatóság észlelt állományát hipotézisünk szerint a partnertől visszavárt és a ténylegesen visszakapott pénzösszegek egyaránt befolyásolják, ezért a játékban nemcsak a tényleges pénzmozgást, hanem az arra vonatkozó várakozásokat is megkérdeztük és követtük. Azt feltételeztük, hogy míg a várakozások beteljesülése erősíti az éppen bizalmat adó fél pozitív véleményét partnerének megbízhatóságáról, addig ellenkező esetben az adott fél által jelzett, észlelt megbízhatóság állománya csökken. Ez azt jelenti, a játékos társának megbízhatóságára vonatkozó észlelése függ az attól aktuálisan ténylegesen viszszakapott összegek nagyságától, de az arra vonatkozó várakozásoktól is.

A következőkben a bizalom kérdéskörét és fogalomrendszerét a bizalomjáték kontextusában először tovább finomítjuk. Majd bemutatjuk az ismételt bizalomjáték általunk kidolgozott változatát és azt a matematikai modellt, mely specifikálja hipotézisünket. Ismertetjük a statisztikai elemzés során felhasznált adatbázis felvételének jellemzöit. Végül összefoglaljuk és értelmezzük eredményeinket, valamint további kutatási irányokat fogalmazunk meg.

\section{A bizalom és a bizalomra méltóság a klasszikus bizalomjátékban}

A kutatásunk középpontjába helyezett alapfogalmak a játékelméleti irodalomban jelennek meg. A bizalomjáték alapesetében két $-A$ és $B-$ játékos vesz részt. Az

\footnotetext{
${ }^{2}$ Természetesen nemcsak üzleti kapcsolatok müködhetnek így, hasonló helyzet adódhat személyközi kapcsolatokban is. Gondoljunk például a házasságokat követő válások azon eseteire, amikor sajnálatos módon a felek közötti korábbi egymásrautaltságot és együttmüködési hajlandóságot az egymást legyőzni kívánó, versengő attitüd váltja fel.
} 
indító játékos rendelkezik pénzzel (jellemzően 10 ECU [experimental currency unit kísérleti valuta]), míg a másik játékosnál az indító játékostól kapott pénz automatikusan megtöbbszöröződik (jellemzően megháromszorozódik vagy megnégyszerezödik). A játékot $A$ játékos indítja, eldönti, hogy a rendelkezésére álló összegből menynyit ad át társának. Az $A$ által átadott összeg $B$ játékosnál - tegyük fel - megháromszorozódik. Ezt követően $B$ játékos eldönti, hogy ebből mennyit juttat vissza $A$-nak. $B$ viszonozhatja $A$ bizalmát azzal, hogy több pénzt ad vissza, mint amennyit a kezdő játékos átadott számára, de dönthet úgy is, hogy nem így tesz, és akár a teljes összeget magánál tartja. Az alapjáték Nash-egyensúlyú $(10,0)$ stratégiája, amikor $A$ játékos nem ad át semmilyen pénzeszközt $B$-nek. Azt azonnal látjuk, hogy ez nem Paretooptimum, ami akkor állna elő, ha $A$ a teljes összeget átadná, így $B$ játékosnál ez az induló 10 ECU megháromszorozódna, vagyis kettőjüknek együttesen 30 ECU-juk lenne. A kérdés az, hogy ebben az esetben $B$ játékos mennyi pénzt ad vissza $A$ játékosnak; ha kevesebb, mint 10 ECU-t, akkor $A$ játékosnak nem érné meg az összes rendelkezésre álló pénzmennyiségét átadnia. Ez azt is megmutatja, hogy az alapjátékban a Pareto-optimum nem stabil, vagyis nem lehet Nash-egyensúly.

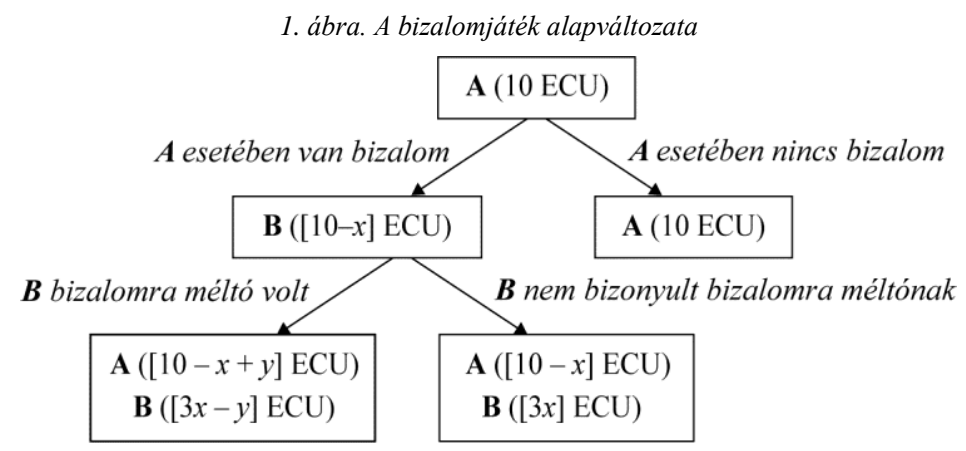

Megjegyzés. $x$ az $A$ játékos által a $B$-nek átadott pénzmennyiség; $y$ pedig a $B$ játékos által az $A$-nak visszaadott pénzmennyiség.

A bizalomjáték klasszikus, egykörös változatában (Berg-Dickhaut-McCabe [1995]) - de az azt követö felhasználásokban is (lásd például Camerer [2003], Ostrom-Walker [2003]) - a bizalomhoz kapcsolódó két fogalom ugyanakkor a szervezetközi kapcsolatok irodalmában kialakult, korábbiakban bemutatottól kissé eltérő módon értelmezhető. A bizalom az indító, azaz $A$ játékoshoz, míg a bizalomra méltóság $B$ játékoshoz kötődik, de mindkettő az adott játékos cselekvéseként értelmeződik, annak mértékét pedig az aktuálisan átadott összeg nagyságával ragadják meg. $A$ játékos esetében a pénz átadása bizalomként értelmeződik, míg $B$-nél egy megfelelő nagyságú pénzösszeg visszajuttatása $A$-nak bizalomra méltóságot jelent. Az $A$ játékos által $B$-nek átadott pénzmennyiség $(x)$ összegével operacionalizáljuk és mérjük a 
bizalmat. A bizalomra méltóságot pedig a $B$ által $A$-nak visszajuttatott összegnek a kapott összeghez viszonyított arányával $(y / 3 x)$ ragadjuk meg (lásd például AshrafBohnet-Piankov [2006]). Hangsúlyozzuk, hogy ebben az értelmezésben mind a két fogalom a játékosok aktuális cselekvésével (flow) áll összefüggésben, és nem tartalmazza a megbízhatóságnak korábban bemutatott, állományjellegủ (stock) értelmezését, mely a játékosok partnerükkel kapcsolatos észleléseit, várakozásait jelenti és a jövőbeni cselekvésekkel kapcsolatos.

A bizalom és a bizalomra méltóság a klasszikus, egykörös bizalomjátékban tehát egyértelmüen kapcsolódik egy-egy játékoshoz. $A$ átad egy bizonyos összeget, mert bizalmat ad társának. $B$, a bizalmat kapó fél, pedig akkor mutatja meg, hogy $A$ számára aktuálisan valóban bizalomra méltó volt-e, ha egy meghatározott minimális vagy a feletti pénzmennyiséget visszajuttat $A$ számára. Ez az egykörös, de akár az ismételt többkörös bizalomjáték esetén is egyértelmü fogalmi elhatárolást biztosít: $A$ játékos mindig a bizalomhoz, $B$ játékos a bizalomra méltóság fogalmaihoz kötődik, hiszen $A$ mindig a bizalmat adó, míg $B$ a bizalmat kapó szituációjában van. A most tárgyalt dinamikus bizalomjátékban ugyanakkor a körök pénzügyi döntéseit összekapcsoltuk, hiszen a partnerek között megosztható összegek a körök során kumulálódtak. Nem az egykörös játék tranzakcióinak puszta ismétlésére került sor, hanem egy dinamikus interakcióra lehetőséget adó játék jött létre. Adott körben $A$ számára éppen rendelkezésre álló összeg mindig az általa korábban át nem adott és $B$ által visszajuttatott pénzmennyiségek teljes, kumulált összege volt. Játékunk e sajátos jellemzőjéből adódik, hogy $A$ és $B$ felváltva hol a bizalmat adó, hol a bizalmat kapó fél pozíciójába került, cselekvéseik jellemzően egyszerre értelmezhetők a hagyományos játékelméleti fogalomhasználat alapján bizalomként és bizalomra méltóságként. Racionális játékosokat feltételezve, ez alól kivétel az utolsó kör, hiszen ebben az esetben elóáll az egykörös bizalomjáték alaphelyzete: $A$ játékos kerül kiszolgáltatott helyzetbe, amivel $B$-nek lehetösége van visszaélni.

2. ábra. A többkörös bizalom játék menete

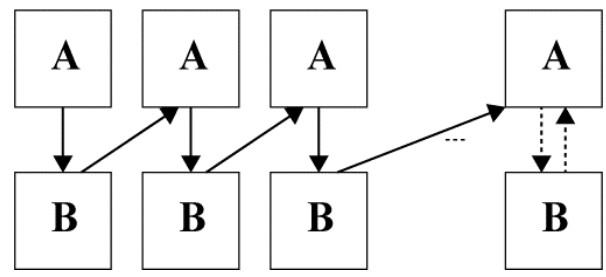

Megjegyzés. $A$ helyzetét, azaz a bizalmat a pontozott nyíl, míg $B$ helyzetét, azaz a bizalomra méltóságot szaggatott nyíl jelzi. A köztes, folytonos nyilak esetében a lépés egyszerre jelent bizalmat és bizalomra méltóságot, attól függően, hogy melyik játékos oldaláról tekintjük az adott lépést. 
Elméletileg mind $A$, mind $B$ játékos dönthet egy adott körben arról, hogy megszakítja az addigi együttműködést, és nem ad vissza pénzt társának. Előfordulhat például, hogy $B$ az utolsó előtti körben mindent átad $A$-nak, hiszen tudja, hogy amennyiben azt $A$ visszajuttatja, az ismét megháromszorozódhat, és ezzel maximalizálhatják a két játékos által közösen elérhető pénzmennyiséget. Ezzel $B$ ugyanakkor kiszolgáltatott helyzetbe kerül, mert $A$ dönthet akár úgy is, hogy semmit nem juttat vissza $B$ számára, ami azt mutatja, $A$ mégsem volt bizalomra méltó az aktuális körben.

A két játékos pozíciói (bizalmat adó vs. bizalmat kapó) ugyan változnak és összecsúsznak a játék során, a két szereplő helyzete mégsem teljesen szimmetrikus, hiszen az első lépés mindig $A$ játékosé, racionális döntéshozókat feltételezve a speciális kifizetőfüggvény (a Nash-egyensúly és a Pareto-optimum egybeesése) miatt pedig az utolsó lépés $B$ játékosé lesz. Mindvégig racionálisan játszó szereplők esetében tehát a többkörös játék végén előáll a klasszikus bizalomjáték szereposztása, az első kör első lépésében $A$ a bizalmat adó (ő van tehát kiszolgáltatott helyzetben), míg az utolsó kör záró lépésekor $B$ a bizalmat kapó fél (akinek lehetősége van ott opportunista viselkedésre).

A játékelmélet hagyományos fogalomhasználatában a bizalomra méltóság $B$ játékos cselekvéseként, míg a szervezetközi kapcsolatokat kutató szakirodalom azt a bizalmat adó fél észleléseként értelmezi. Tudomásunk szerint sem az angol, sem a magyar nyelvủ szakirodalom nem tesz javaslatot arra, hogy a trustworthy e két kapcsolódó, koncepcionálisan mégis eltérö fogalmára milyen megkülönböztető kifejezéseket használjunk. Mi a továbbiakban a cselekvésben megnyilvánuló bizalomra méltóság esetén használjuk ezt a magyar kifejezést. Amikor azonban annak állományjellegü értelmezéséről, tehát a bizalmat adó félnek a bizalmat kapó félre vonatkozó észleléseiről, várakozásairól van szó, akkor a megbízhatóság kifejezést alkalmazzuk. A továbbiakban cikkünkben így teszünk különbséget a két koncepció között.

A szakirodalomban fellelhető néhány olyan kutatás, mely a megbízhatóság kérdésének elemzését beépíti a bizalomjátékba. Chang et al. [2010] például kutatásaikban azt vizsgálták, hogyan befolyásolja a felek döntéseit (a bizalomra méltóságot) a partnerrel kapcsolatos első impressziójuk, ami gyakorlatilag a partner megbízhatóságára vonatkozó észleléseiket befolyásolja. Mások a reputáció hatását elemzik, ami szintén az adott fél észlelt megbízhatóságát befolyásolja (Boero et al. [2009]). Tudomásunk szerint ugyanakkor olyan kísérletet még nem végeztek, mely egy többkörös játék keretei között közvetlenül mérte volna a megbízhatóságra vonatkozó aktuális észleléseket. A szakirodalomban található olyan munka is, mely a visszakapott pénzre vonatkozó várakozások mérését építi be a játékba. Chaudhuri és Gangadharan [2007] például az egykörös bizalomjátékot összekötötték az egykörös diktátorjátékkal, s ennek során a játékosoktól megkérdezték, hogy mekkora összeget várnak vissza társuktól. Eredményeik szerint az egykörös bizalomjátékban a reciprocitásra vonatkozó 
várakozások (azaz a visszavárt összegek nagysága) hatnak a bizalom szintjére ( $A$, azaz a játékot kezdő fél cselekvésére). Játékunkban mi mind az észlelt bizalomra méltóság szintjére, mind a visszavárt összegekre direkt módon, a játék valamennyi körében rákérdeztünk, hiszen azt feltételeztük, hogy a visszavárt és a ténylegesen visszakapott összegek hatnak a partner észlelt megbízhatóságának szintjére.

A következőkben modellezzük hipotézisünket, részletesen ismertetjük azt a módosított bizalomjátékot, melyet modellünk tesztelésére kidolgoztunk. Bemutatjuk a játék lebonyolításának menetét és körülményeit, majd az adatfelvétel eredményeként rendelkezésre álló 49 játékospár döntéseit tartalmazó adatbázisunk felhasználásával, többváltozós regresszió segítségével teszteljük hipotézisünket. Munkánkat az eredmények értelmezésével, az elvégzett kutatás korlátainak tárgyalásával és újabb kutatási irányok megfogalmazásával zárjuk.

\section{A módosított bizalomjáték és a játékosok viselkedésének modellezése}

Hipotézisünk tesztelése érdekében szükségünk volt az alapjáték dinamizálására. Az ismétlés megengedésével tudjuk ugyanis vizsgálni az észlelt megbízhatóság időbeli alakulását az adott játékospárok esetében, és annak hatását magára a bizalomra mint kockázatos cselekvésre.

A következőkben bemutatjuk a bizalomjáték dinamizálása során használt változókat és paramétereket.

\subsection{A döntési változók}

A modellezés során a következő döntési változókkal dolgozunk:

- $I_{t}^{A}:$ az $A$ játékos $t$-edik kör végén rendelkezésre álló ECUállománya;

- $I_{t}^{B}$ : a $B$ játékos $t$-edik kör végén rendelkezésre álló ECU-állománya;

$-x_{t}$ : a $t$-edik periódusban $A$ játékos által $B$ játékosnak átadott ECU mennyisége;

$-y_{t}$ : a $t$-edik periódusban $B$ játékos által $A$ játékosnak átadott ECU mennyisége;

$-T$ : a lejátszott körök száma. 
A döntési változók segítségével a következő pénzügyi egyensúlyi feltételeket írhatjuk fel, feltételezve, hogy $A$ játékosnak 10 ECU áll rendelkezésére az induló, 0 -dik időpontban, és $B$ játékos a játék elején nem rendelkezik pénzeszközzel.

$$
\begin{aligned}
& I_{t}^{A}=I_{t-1}^{A}-x_{t}+y_{t}, \quad I_{0}^{A}=10 E C U \\
& I_{t}^{B}=I_{t-1}^{B}+3 \cdot x_{t}-y_{t}, \quad I_{0}^{B}=0 E C U
\end{aligned} t=1,2, \ldots, T
$$

Feltételezzük továbbá, hogy az átadott pénzmennyiségek nemnegatívak, vagyis $x_{1} \geq 0, y_{1} \geq 0$. Amennyiben a játékosok célja a játék végén közösen elért pénzmennyiség maximalizálása, akkor az előbbi egyenlőségekhez a következő célfüggvényt rendelhetjük:

$$
I_{T}^{A}+I_{T}^{B} \rightarrow \max
$$

E dinamikus optimalizálási feladat megoldásait a Pareto-optimumok képezik. Az látható, hogy a maximálisan elérhető pénzmennyiség értéke $10 \cdot 3^{T} \mathrm{ECU}$, amennyiben $A$ játékos minden periódusban az összes nála levő pénzmennyiséget átadja $B$ játékosnak $\left(x_{t}^{o}=10 \cdot 3^{t-1},(t=1,2, \ldots, T)\right)$, akinél az automatikusan megháromszorozódik $\left(y_{t}^{o}=10 \cdot 3^{t},(t=1,2, \ldots, T-1)\right)$, majd a megnövekedett összeget $B$ visszaad(hat)ja párjának. Azt, hogy a rendelkezésre álló pénzmennyiség hogyan oszlik meg a játékosok között, legkésőbb az utolsó periódusban $B$ játékos döntheti el azzal, hogy mennyit tart meg, és mennyit ad át $A$ játékosnak, vagyis folyamatos együttmüködés esetén az utolsó körben $y_{T}^{o}=10 \cdot 3^{T}-\tilde{x}$, ahol $\tilde{x} 0$ és $10 \cdot 3^{T}$ között levő szám.

Mint korábban már említettük, modellünkben a klasszikus (az elért ECU-val arányos) helyett két speciális kifizetőfüggvényt $-F_{A}\left(I_{T}^{A}\right)$ és $F_{B}\left(I_{T}^{B}\right)$ - állítottunk fel:

$$
F_{A}\left(I_{T}^{A}\right)=G \cdot \delta\left(I_{T}^{A}-I_{T}^{B}\right)+\frac{I_{T}^{A}+I_{T}^{B}}{10 \cdot M^{T}} \cdot K
$$

valamint

$$
F_{B}\left(I_{T}^{B}\right)=G \cdot \delta\left(I_{T}^{B}-I_{T}^{A}\right)+\frac{I_{T}^{A}+I_{T}^{B}}{10 \cdot M^{T}} \cdot K
$$

ahol $G$-a győztesnek járó prémium összege; $K$-a közösen szerzett összes ECU alapján járó jutalom; $M$ - a befektetési szorzó; $T$ - a körök száma. 
Esetünkben ezek a paraméterek a következőképpen alakultak: $G=500$ forint, $K=1000$ forint, $M=3$, és a körök száma 10 volt. Mint azt már hangsúlyoztuk, játékunk lényegesen eltér valamennyi korábbi ismételt bizalomjátéktól abban, hogy adott körben az elöző körökben elért összes pénzösszeget befektethetővé tettük, ezzel a felek számára a 10 körös kapcsolatukban együttműködve versengő helyzetet teremtettünk.

A $\delta$ (.) függvényt a következő módon definiáljuk:

$$
\delta(z)=\left\{\begin{array}{cc}
0 & z<0, \\
\frac{1}{2} & z=0, \\
1 & z>0 .
\end{array}\right.
$$

A játék során felmerülő döntési helyzeteket sorrendben visszafelé elemezve, racionális játékosokat feltételezve könnyen belátható, hogy az utolsó lépésben $B$ játékos számára a kifizetési ösztönző vonzata minden $I_{t}^{B}$ esetén $y_{T}=0$. Az utolsó lépésben tehát $A$ játékos célja $\max \left(F_{A}\right)$ úgy, hogy tudja, nem számíthat $B$-től további visszakapott pénzre. Ez a cél tehát kibontható a következő alakra:

$$
\max _{x_{T}}=\left\{G \cdot \delta\left(\left(I_{T-1}^{A}-x_{T}\right)-\left(I_{T-1}^{B}+x_{T} \cdot 3\right)\right)+\frac{\left(I_{T-1}^{A}-x_{T}\right)+\left(I_{T-1}^{B}+x_{T} \cdot 3\right)}{10 \cdot M^{T}} \cdot K\right\} .
$$

A függvény a paraméterek állapota (a játék állása) szerint különbözőképp adja meg az optimális $x_{T}$ értéket. $^{3}$

1. Amennyiben $\left(I_{T-1}^{A} \leq I_{T-1}^{B}\right)$, az $A$ játékosnak nincs lehetősége optimalizálni, és nem érdeke az együttmüködés: $x_{T}=0$.

2. Amennyiben $\left(I_{T-1}^{A} \leq I_{T-1}^{B}\right)$, az $A$ játékosnak van mozgástere eldönteni, a közösen szerzett pénzt érdemes növelnie, melynek kifizetö szorzója $K$, vagy a győzelmi prémiumot $(G)$ érdemes megszereznie. Ez függ egyrészt $G$ és $K$ arányától és az eddig megszerzett összes ECU mennyiségének a maximálisan megnyerhető összeghez viszonyított arányától: $\alpha=\frac{I_{T-1}^{A}+I_{T-1}^{B}}{10 \cdot M^{T-1}}$.

\footnotetext{
${ }^{3}$ Képletünk nem más, minta a Bellmann-féle dinamikus programozás backward indukciója, így gondolatmenetünk a dinamikus optimalizálás témaköréhez is kapcsolódik.
} 
a) Ha $\alpha<1$, tehát bármelyik korábbi lépésben nem a maximális összeget adták a játékosok egymásnak, akkor $A$ játékos maximalizáló stratégiája az, hogy átad annyit, amivel még mindig neki marad több (a győzelmi prémium biztos megtartása):

$$
x_{T}^{*}=\left(I_{T-1}^{A}-I_{T-1}^{B}\right) / 3-1 .
$$

b) Ha $\alpha=1$, tehát eddig minden lépésben maximális összeget adtak a játékosok egymásnak, $y_{T}=0$ feltételezésével sincs olyan $x_{T}$, ami a győzelmi prémium biztos megtartásával jobb eredményre vezetne, mint a teljes összeg átadása.

Mivel $G+\left(I_{T-1}^{A}-x_{T}+3 \cdot x_{T}\right) \cdot K<K$, ezért a maximalizáló stratégia:

$$
x_{T}=\left(I_{T-1}^{A}\right) .
$$

Mindezek alapján $T-1$ időpontban, ha addig a lépésig 100 százalékban együttmüködtek a felek (azaz a teljes rendelkezésre álló összeget átadták), $B$ játékos maximalizáló stratégiája szintén a teljes összeg átadása, mert tudja, hogy $A$ játékosnak megéri azt egészében visszaadni, amit aztán $B$ a végén megtarthat. Innen visszavezethető, hogy $y_{T}$ kivételével minden olyan lépésben, amelyet megelőzően a teljes rendelkezésre álló összeget átadják a játékosok egymásnak, a teljes rendelkezésre álló összeg átadása a maximalizáló stratégia. Ezen lépések sorából nem kivétel az első $x_{1}$ lépés sem, ami által megbomlik a játék klasszikus egyensúlya, és a kifizetőfüggvény miatt minden lépésben a teljes rendelkezésre álló összeg átadása lesz a maximalizáló stratégia. Az egyensúlyi pont így egyszerre Pareto-optimum és Nash-egyensúlyi.

\subsection{Az alapmodell kiterjesztése a megbízhatóság koncepciójával}

Elméleti bevezetésünkben már bemutattuk, hogy a megbízhatóság fogalom állományváltozónak tekinthető, és elvileg minden időpontban meghatározható, mérhető. Ezt a változót úgy operacionalizáltuk, hogy annak állományára 1-től 5-ig tartó szöveges skálán $(1=$ egyáltalán nem, 5 = nagyon megbízik $)$ kérdeztünk rá közvetlenül.

Modellünk döntési változóinak körét így a két játékos megbízhatóságának észlelt szintjével, állományával bővítettük ki:

- $R_{t}^{A} \quad A$ játékos megbízhatóságának szintje, ahogyan azt a $t$-edik időpontban $B$ játékos észleli; 
- $R_{t}^{B} B$ játékos megbízhatóságának szintje, ahogyan azt a $t$-edik időpontban $A$ játékos észleli.

Az állományjellegü változókon kívül bevezettük a két játékos ún. várakozási függvényét is, ami azt mutatja, hogy a felek adott periódusban mekkora pénzösszeget várnak vissza a játékostársuktól. A két várakozási függvény:

$-x_{t}^{e}\left(y_{t}\right) B$ játékos azon várakozása, hogy mekkora összeget kap $A$-tól a $t$-edik periódusban;

$-y_{t}^{e}\left(x_{t}\right) A$ játékos azon várakozása, hogy mekkora összeget kap

$B$-töl a $t$-edik periódusban.

A várakozási függvények segítségével modelleztük a megbízhatóság időbeli változását. Adott játékos észlelt megbízhatóságának változását modellünkben és a statisztikai elemzés során is a másiktól visszavárt és a ténylegesen visszakapott pénzösszegek függvényében ragadtuk meg. Azt feltételeztük, hogy a megbízhatóság szintjére mint egyfajta bizalmi tőkére mind a visszavárt összegre vonatkozó várakozások, mind a ténylegesen visszakapott összegek hatnak. Ezek alapján a megbízhatóság alakulását függvényszerủen a következő módon fejeztük ki:

- $f^{A}\left(y_{t}^{e}\left(x_{t}\right), y_{t}\right) A$ játékos megbízhatóságának változási függvénye azt mutatja meg, hogy mennyivel változott $A$ játékos megbízhatóságának szintje a $t$-edik periódusban (ez a $B$ játékos észlelése). Ez az adott periódusban $B$ által visszavárt és $A$-tól ténylegesen visszakapott pénzmennyiségek nagyságaitól függ.

- $f^{B}\left(x_{t}^{e}\left(y_{t}\right), x_{t}\right) B$ játékos megbízhatóságának változási függvénye azt mutatja meg, hogy mennyivel változott $A$ játékos megbízhatóságának szintje a $t$-edik periódusban (ez az $A$ játékos észlelése). Ez az adott periódusban $A$ által várt és $B$-től ténylegesen visszakapott pénzmennyiségek nagyságaitól függ.

A megbízhatóság változásának diszkrét differenciaegyenlet-rendszerét ezzel a következő módon értelmeztük:

$$
\begin{aligned}
& R_{t+1}^{A}=R_{t}^{A}+f^{A}\left(y_{t}^{e}\left(x_{t}\right), y_{t}\right), R_{0}^{A}=0, \\
& R_{t+1}^{B}=R_{t}^{B}+f^{B}\left(x_{t}^{e}\left(y_{t}\right), x_{t}\right), R_{0}^{B}=0 .
\end{aligned}
$$


A változók és a paraméterek bevezetése után, összefoglaló jelleggel a 3. ábrán szemléltetjük dinamizált bizalomjátékunk időbeli lefolyását.

3. ábra. A dinamizált bizalomjáték időbeli lefolyása

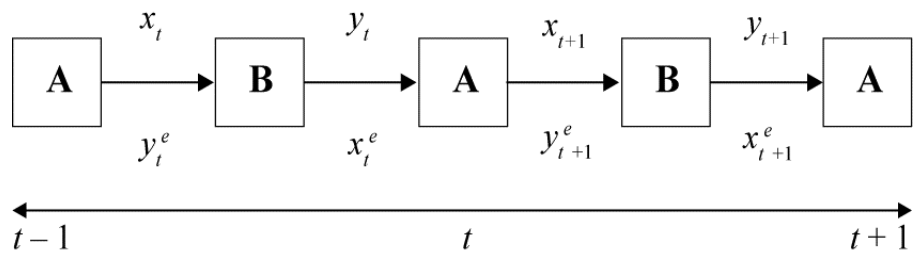

\section{A játék folyamata és az adatfelvétel}

A kísérlet résztvevői a Budapesti Corvinus Egyetem diákjai voltak, akiket elsősorban az egyetem belső hírlevelén keresztül értünk el. Bennünket alapvetően az üzleti kapcsolatokban zajló jelenségek érdekeltek. Korábbi kutatások igazolták ugyanakkor, hogy a gazdasági képzésben részt vevő hallgatók viselkedése nem különbözik jelentősen az üzleti szereplökétöl (Bolton-Ockenfels-Thonemann [2012]). Ezért a hallgatói minta alapján levont következtetések nagy valószínűséggel az üzleti szereplők interakcióira is igaznak tekinthetők. A jelentkezés a játékra és a részvétel önkéntes volt. A kísérletekre az egyetem számítógépes laborjában került sor, a játék során a párok számítógépen keresztül kerültek kapcsolatba egymással. Minden esetben két kutató részvételével zajlott az adatfelvétel. Az adathalmazt 7 játékalkalommal sikerült összegyüjteni 49 pártól. Ez azt jelenti, hogy átlagosan 7 pár volt jelen egy 30 fős teremben az adatfelvételkor, és egyetlen alkalommal sem haladta meg a párok száma a 10-et. A terem nagysága és az adatfelvétel során jelen levő hallgatói létszám lehetővé tette, hogy nagyobb távolságokra üljenek egymástól a felek, és ne lássák egymás képernyőit sem, tehát véletlenül se tudják beazonosítani egymást az aktuális párok. Elsőként a tájékoztatót osztottuk ki számukra, melyben a játék szabályait, menetrendjét és a szükséges számítógépes instrukciókat rögzítettük. (Lásd a Függeléket.) Az ennek átolvasásához igényelt idő változó hosszúságú volt, de a szükséges időkeretet mindig biztosítottuk. Amennyiben valaki kézfeltartással jelezte, hogy kérdése van, azt vele személyes konzultációban, a többieket nem befolyásolva tisztázni tudtuk. Egy-egy adatfelvétel teljes ideje (ültetés, instrukciók elolvasása, esetleges kérdések tisztázása, maga a játék, majd a nyeremény kifizetése) jellemzően szük másfél órát vett igénybe. A tényleges játék jellemzően 30 percig tartott. A résztvevők a tájékoztatón aláirásukkal igazolták, hogy az adatfelvétel korábbi fordu- 
lóiban még nem vettek részt. A játék végén a játékosok elhagyták a labort, az elért eredmény és a kifizetöfüggvény által meghatározott tényleges nyereményüket egy távolabb található teremben tudták felvenni. A modell számítógépes verzióját magunk fejlesztettük ki és programoztuk (Excelben). A 4. ábra programunk kezdő felületét mutatja $B$ játékos esetében.

4. ábra. A B játékosok kezelöfelülete a programban

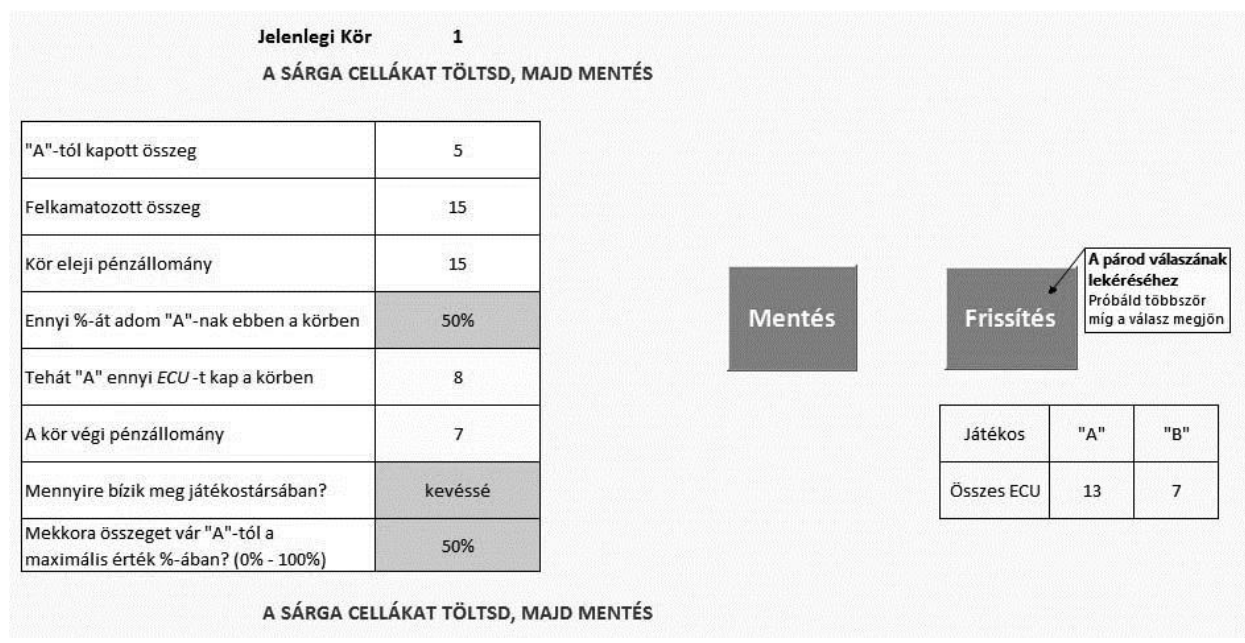

Megjegyzés. A kezelőfelület sárga cellái itt világosszürkével láthatók.

Mindkét játékos számára látható volt az adott körben megkapott összeg, $B$ játékos esetében annyi különbséggel, hogy külön tételként jelent meg az $A$-tól kapott összeg 3-szoros szorzóval megnövelt értéke is. A játékosoknak azt kellett az egyes körökben megadniuk, hogy az összes rendelkezésre álló pénzállomány mekkora részét adják át az adott körben a másik játékos számára. A program a százalékosan megadott összeget ECU-ban kiszámolta, és mutatta az átadás utáni ECU-megoszlás aktuális állapotát is. A játékosoknak emellett minden körben meg kellett adniuk a másik játékosról alkotott véleményüket is a megbízhatóság tekintetében (1-től 5-ig terjedő szöveges skálán). Az aktuális véleményüket pedig minden körben egy legördülő menüböl kellett kiválasztaniuk. Továbbá azt is meg kellett adniuk százalékban kifejezve, hogy a játékostárs összes rendelkezésre álló pénzéből mekkora arányban várnak vissza pénzösszeget. A kísérletünkkel azt céloztuk megfigyelni, hogy a várakozások és a tényleges visszautalások befolyásolják-e a megbízhatóság szintjének változását, tehát azt, hogy a játékos mennyire tartja társát megbízhatónak. 


\section{A statisztikai elemzés eredményei}

Az adatfelvétel mind értékben (ECU), mind százalékos arányban biztosított adatokat elemzésünk számára, mindkét esetben elvégeztük számításainkat, melyek nem mutattak lényegesen eltérő eredményt. Ezért ebben a fejezetben alapvetően a százalékos eredményeket tárgyaljuk. Elsőként a modellhez szükséges változók alapsokaságának leíró statisztikáiról lesz szó, ezt követően a hipotézisünk kapcsán végzett regressziós modellek eredményeit mutatjuk be. Fontos megjegyezni, hogy a 49 pár által játszott, egyenként 10 körből álló bizalomjáték minden köre, azaz tranzakciója az alapsokaság egy-egy elemének tekinthetö, hiszen a kutatásunk szempontjából kiemelt kérdés, hogy a megbízhatóság változása tranzakciókhoz kötött-e, és tranzakciók alapján történt-e a megkérdezés. Az alapsokaságunk nagysága így $N=490$.

1. táblázat

A bizalomjáték változóinak átlagértéke és szórása $(N=490$ tranzakció)

\begin{tabular}{l|c|c}
\hline \multicolumn{1}{c|}{ Változó } & Átlag & Szórás \\
\hline$x_{t}-A$ által átadott ECU az adott körben rendelkezésre álló teljes összegből (\%) & 69,9690 & 36,33823 \\
\hline$y_{t}-B$ által átadott ECU az adott körben rendelkezésre álló teljes összegből (\%) & 68,3903 & 33,21326 \\
\hline$x_{t}^{e}-B$ által visszavárt ECU az adott körben rendelkezésre álló teljes összegből (\%) & 71,3020 & 30,62369 \\
\hline$y_{t}^{e}-A$ által visszavárt ECU az adott körben rendelkezésre álló teljes összegből (\%) & 66,7061 & 32,45868 \\
\hline$\delta R_{t}^{A}-A$ megbízhatóságában bekövetkezett változás az adott tranzakcióban, ahogyan & & \\
azt $B$ észleli (1-től 5-ig terjedő skála) & $-0,0160$ & 0,67360 \\
\hline$\delta R_{t}^{B}-B$ megbízhatóságában bekövetkezett változás az adott tranzakcióban, ahogyan & & \\
azt $A$ észleli (1-től 5-ig terjedő skála) & $-0,0080$ & 0,80380 \\
\hline
\end{tabular}

A játékot indító $A$ játékosok ECU-juk átlagosan közel 70,0 százalékát adták át partnereiknek. Várakozásaik ennél valamivel alacsonyabb arányt tükröztek, a rendelkezésre álló teljes összeg átlagosan 66,7 százalékára vonatkoztak. $B$ játékosoknál pont fordított jelenséget figyelhettünk meg, a visszavárt összegek a rendelkezésre álló teljes pénzállománynak 71,3 százalékára vonatkoztak, míg ők csak annak 68,4 százalékát adták vissza ténylegesen. A visszavárt és a ténylegesen visszakapott összegek tekintetében a kétféle játékosok között tehát kis különbségeket tapasztaltunk, e kis eltérések irányára ugyanakkor magyarázatul szolgálhat pozíciójuk korábbiakban már tárgyalt különbözősége. E szerint ugyan a felek a játék közbülső köreiben párhuzamosan vannak a bizalmat adó és a bizalmat kapó pozíciójában, racionális döntések esetén összességében mégis igaz a klasszikus, egykörös bizalomjáték alaphelyzete, azaz $A$ játékosok 
vannak kiszolgáltatott helyzetben, míg $B$ játékosok dönthetnek arról, hogy ezt mennyire használják ki, azaz viselkednek opportunista módon. Az 1. táblázatból az is látszik, hogy a játékosok társuk megbízhatóságára vonatkozó észleléseinek változása igen kicsi, de negatív, azaz a megbízhatóság csökkenő, még ha igen kis mértékben is.

Amennyiben az egyes játékosok által átadott és az általuk visszavárt összegek időbeli alakulását nézzük, egy lapos, fordított U-alakú görbét kapunk mindkét játékostípus esetében. A játékosoknál az átadott összegek átlaga az első körben 52,9 százalék volt, ami az ezt követö két körben viszonylag nagyot emelkedett, majd a 4-8. körökben stabilizálódott. Az utolsó két körben jelentősen csökkentek az A játékosok által átadott és visszavárt értékek is. Hasonlóképpen alakult $B$ játékosok esetében is a görbe, azzal a különbséggel, hogy $B$ játékosok az első körben nagyobb összegeket adtak át párjaiknak. Ezt követően az összegek kisebb mértékben növekedtek, mint $A$ játékosok esetében. Mindkét félnél a maximális arányok 78-80 százalék körüliek voltak. Ez azért érdekes eredmény, mert korábbi kutatások akkor tekintettek egy játékost adott tranzakcióban bizalomra méltónak, ha az általa visszajuttatott összeg elérte, vagy meghaladta a teljes rendelkezésre álló összeg 80 százalékát (Chang et al. [2010]). Ez az arány játékunkban is kritikus értéknek bizonyult.

5. ábra. A játék 10 köre során a játékosok által átadott és visszavárt átlagos ECU

a teljes összeg százalékában

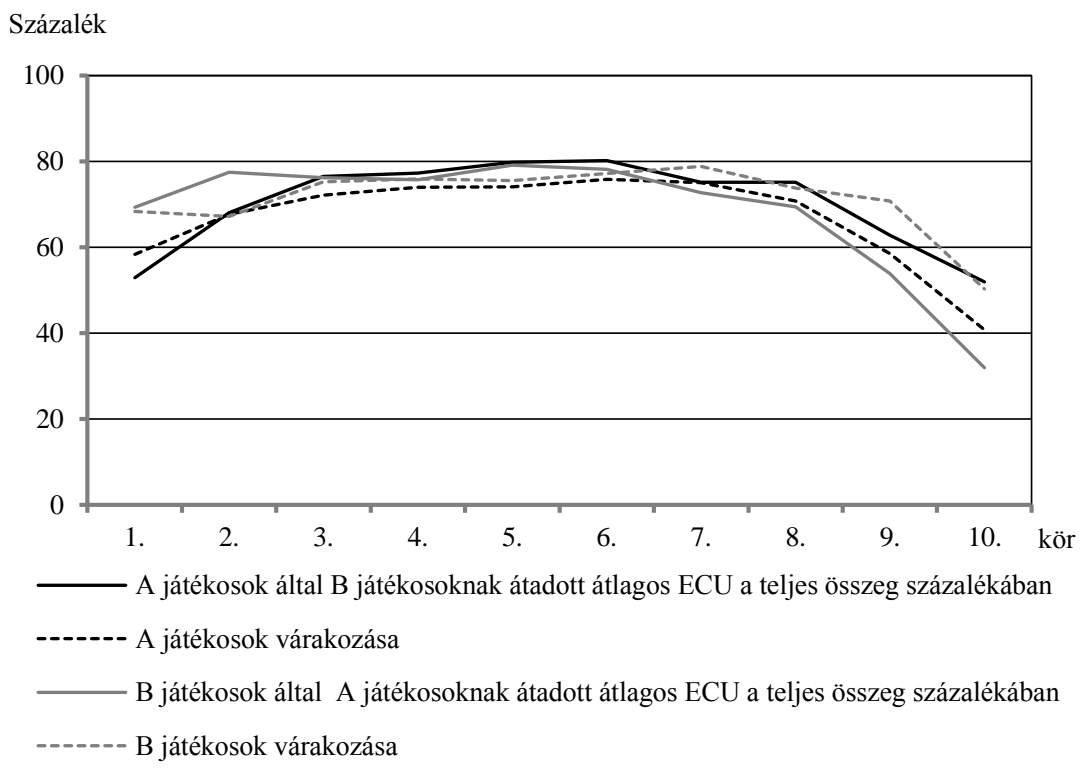

$B$ játékosok a játék utolsó köreiben $A$ játékosokhoz képest nagyobb mértékben csökkentették az átadott összegeket. Az egyes játékosok társuktól visszavárt összegei 
és az általuk társuknak átadott összegek együtt mozogtak. A játék utolsó köreiben fordult elő, hogy $B$ játékosok jelentősebb összeget vártak vissza társuktól, mint amennyit azoknak visszaadtak. Ezek a fordított U-alakú görbék értelmezésünkben arra utalnak, hogy a játék során megfigyelhető egy tanulási szakasz (1-3. kör), ahol a játékosok - úgy tünik - még nem értették meg teljesen a szabályokat, így nem is viselkedtek racionálisan (a teljes összeg át- és visszaadása tekintetében). A 4-8. körben a játékban átadott összegek 80 százalék körül stabilizálódtak. Itt a racionális viselkedés (a teljes összeg átadásának) hiánya szerintünk kevésbé a játék megértésében rejlő problémákra, mint inkább a bizalmatlanságra vezethető vissza. Az utolsó körökben mind a várakozások, mind a ténylegesen átadott összegek csökkentek, ami a felek által észlelt növekvő kockázatot és ezzel párhuzamosan a bizalom hiányának növekedését is mutathatja.

A megbízhatóság induló szintjének átlagértéke az 1-től 5-ig terjedő skálán 3,71 volt, ami inkább pozitív attitüdöt, várakozást tükröz a játékosok részéröl. A játék során a felek partnerük megbízhatóságára vonatkozó észlelései időben nagyon kis mértékben változtak. A változások itt is a játék kezdő (1-2.) és befejező (8-10.) köreiben voltak valamivel eröteljesebbek, de azok így is minimálisnak tekinthetők. Érdekes, hogy mindkét játékos esetében az utolsó kör a megbízhatóság korábbinál valamivel jelentősebb erősödését hozta magával. Mivel $A$ és $B$ játékosok a 10 körös játék utolsó körében a klasszikus egykörös bizalomjáték alappozícióiban vannak ( $A$ bizalmat ad, míg $B$ bizalmat kap), ez a növekedés arra utal, hogy a játékospárok a záró körben társuk megbízhatóságával kapcsolatban pozitívan nyilatkoztak.

A megbízhatóság változásának igen alacsony szintje az adott játékosok által társuktól visszavárt és a ténylegesen visszakapott összegek közötti eltérések kis mértékével magyarázható. A 6 . ábra azt mutatja, hogy $A$ játékosok esetében a játék első köreiben a várakozások kisebbek voltak, mint a visszakapott összegek, ami a játék végére fordítottan alakult, a különbségek azonban itt sem voltak nagyok. A köztes körökben nagyságrendileg megegyeztek a visszavárt és a ténylegesen visszakapott összegek. A játék elején fordított helyzet alakult ki $B$ játékosok esetében, akik többet vártak vissza társuktól, mint amennyit ténylegesen kaptak. Ezt követően $B$ játékosoknál a várt és a visszakapott összegek végig nagyjából megegyeztek. Ezek az adatok is alátámasztják a tanulási szakasszal korábban már említett jelenséget.

A 6. ábrán látható, hogy a megbízhatóság észlelt értékeinek változásai igen kicsik. A játék végén ugyanakkor megfigyelhető egy markánsabb erősödés, mely a visszavárt és a ténylegesen visszakapott összegek alakulásával nem magyarázható. Ugyanakkor több pár esetében előfordult az a jelenség, hogy a nyertes fél a kifizetőfüggvényben a győztesnek járó prémium összegét megosztotta partnerével. Feltételezzük, hogy a játékosok várakozásaiban ennek a prémiumnak a megosztása nem jelent meg, erre nem is gondolhattak. Ezért annak bekövetkezése meglepetésszerüen hathatott, és a megbízhatósággal kapcsolatos észleléseket pozitívan befolyásolta. 
6. ábra. A játék 10 köre során a játékosok által (az 1-töl 5-ig terjedö skálán) jelzett megbizhatóság változásának átlagos értékei

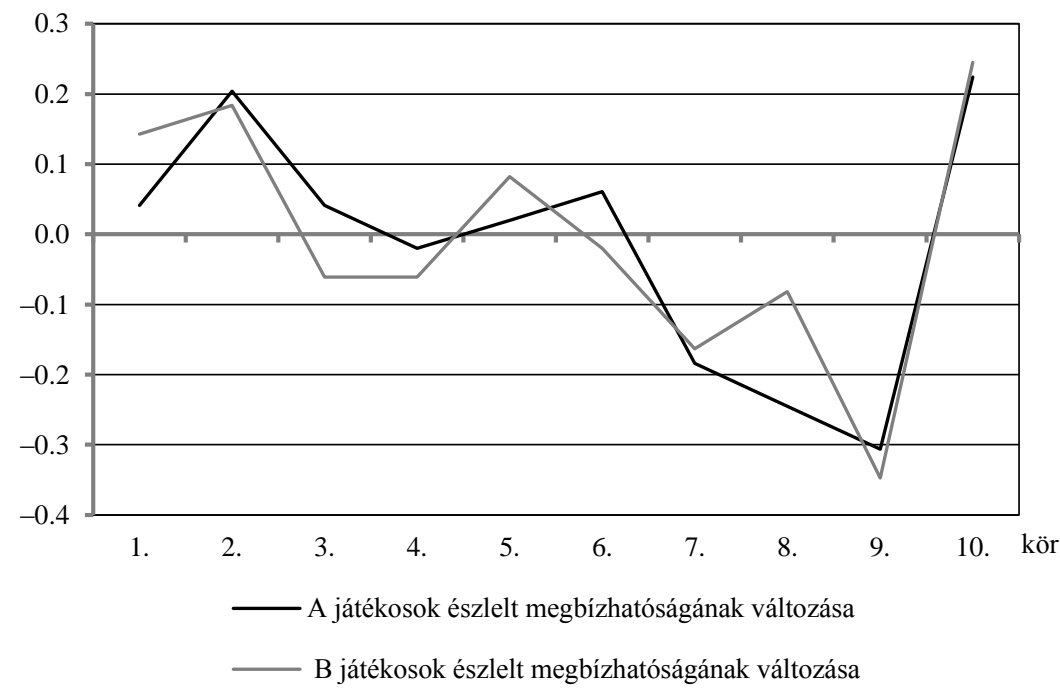

Elméleti modellünk érvényességének vizsgálatát, s ezzel hipotézisünk tesztelését a megbízhatóság változását megragadó differenciaegyenlet regressziós tesztelésével végeztük el.

A differenciaegyenlet-rendszer egyszerủ átalakítás után a következő:

$$
\begin{aligned}
& R_{t+1}^{A}-R_{t}^{A}=f^{A}\left(y_{t}^{e}\left(x_{t}\right), y_{t}\right), \\
& R_{t+1}^{B}-R_{t}^{B}=f^{B}\left(x_{t}^{e}\left(y_{t}\right), x_{t}\right) .
\end{aligned}
$$

Ez egyben azt is mutatja, hogy a differenciaegyenlet-rendszer megoldása visszavezethető egy regressziós modellére. Az SPSS 22-es programcsomag lineáris regressziós modelljét alkalmazva azt is vizsgáltuk, hogy a párokat alkotó játékosok által észlelt megbízhatóság szintje hogyan alakult. A játékospárok szereplőire (azaz $A$ és $B$ játékosokra) az eredményeket a 2. táblázat mutatja. ${ }^{4}$

\footnotetext{
${ }^{4}$ Olyan regressziós modelleket is kialakítottunk, melyek változóként az aktuális kör, a tranzakció számát is tartalmazták. Ekkor a modellek szignifikánsak voltak. $A$ játékosok esetén a kapott $R^{2} 0,065$, míg $B$ játékosok esetén az $R^{2}$ értéke 0,035 lett. Ezek az alapmodellhez képest valamivel rosszabb eredmények. A modellekben az idő együttható nem bizonyult szignifikánsnak.
} 
2. táblázat

A játékosok megbizhatósági szintjének alakulása (százalékos adatok felhasználásával)

\begin{tabular}{|c|c|c|}
\hline \multirow{2}{*}{ Mutató } & $A$ & $B$ \\
\hline & \multicolumn{2}{|c|}{ játékosok megbízhatósági szintje } \\
\hline & \multicolumn{2}{|c|}{ Regresszió } \\
\hline$R$ & 0,333 & 0,292 \\
\hline$R^{2}$ & 0,111 & 0,085 \\
\hline Korrigált $R^{2}$ & 0,108 & 0,081 \\
\hline Véletlen tényező becsült szórása & 0,636 & 0,770 \\
\hline Négyzetösszeg & & \\
\hline Regresszió & 24,661 & 26,890 \\
\hline Maradványérték & 197,208 & 289,077 \\
\hline Összesen & 221,869 & 315,967 \\
\hline \multicolumn{3}{|l|}{$\mathrm{d} f$} \\
\hline Regresszió & 2 & 2 \\
\hline Maradványérték & 487 & 487 \\
\hline Összesen & 489 & 489 \\
\hline \multicolumn{3}{|l|}{ Átlagos négyzetösszeg } \\
\hline Regresszió & 12,331 & 13,445 \\
\hline Maradványérték & 0,405 & 0,594 \\
\hline \multicolumn{3}{|l|}{$F$} \\
\hline Regresszió & 30,450 & 22,651 \\
\hline \multicolumn{3}{|l|}{ Maradványérték } \\
\hline \multicolumn{3}{|l|}{ Szignifikancia } \\
\hline Regresszió & 0,000 & 0,000 \\
\hline \multicolumn{3}{|l|}{ Maradványérték } \\
\hline & \multicolumn{2}{|c|}{ Együtthatók } \\
\hline \multicolumn{3}{|l|}{$B^{*}$} \\
\hline Konstans & 0,003 & 0,044 \\
\hline Döntési változó $\left(x_{t} ; y_{t}\right)$ & 0,007 & 0,007 \\
\hline Várakozási változó $\left(x_{t}^{e} ; y_{t}^{e}\right)$ & $-0,007$ & $-0,008$ \\
\hline \multicolumn{3}{|l|}{ Standard hiba* } \\
\hline Konstans & 0,077 & 0,089 \\
\hline Döntési változó $\left(x_{t} ; y_{t}\right)$ & 0,001 & 0,001 \\
\hline Várakozási változó ( $\left.x_{t}^{e} ; y_{t}^{e}\right)$ & 0,001 & 0,001 \\
\hline
\end{tabular}

(A táblázat folytatása a következö oldalon.) 


\begin{tabular}{l|c|c}
\hline \multirow{2}{*}{ Mutató } & $A$ & $B$ \\
\cline { 2 - 3 } & \multicolumn{2}{c}{ játékosok megbízhatósági szintje } \\
\hline \multirow{2}{*}{$t$} & & \\
\hline Konstans & 0,036 & 0,490 \\
\hline Döntési változó $\left(x_{t} ; y_{t}\right)$ & 7,199 & 5,518 \\
\hline Várakozási változó $\left(x_{t}^{e} ; y_{t}^{e}\right)$ & $-6,200$ & $-6,150$ \\
\hline Szignifikancia & & \\
\hline Konstans & 0,971 & 0,625 \\
\hline Döntési változó $\left(x_{t} ; y_{t}\right)$ & 0,000 & 0,000 \\
\hline Várakozási változó $\left(x_{t}^{e} ; y_{t}^{e}\right)$ & 0,000 & 0,000 \\
\hline
\end{tabular}

* Nem standardizált együtthatók.

Megjegyzés. $\delta R_{t}^{A}$ és $\delta R_{t}^{B}$ a függőváltozók.

Mint látjuk, a regressziós modellek együtthatói szignifikánsak, de viszonylag alacsony $R^{2}$ értékeket kaptunk. Megjegyezzük, hogy a kapcsolati jelenségeket kutató pszichológiai szakirodalomban ezek az eredmények nem tekinthetők rossznak. Számításaink eredménye - miszerint modellünk nagyon alacsony $R^{2}$ mellett szignifikáns volt - szintén gyakori jelenség más társadalomtudományi vizsgálatokban (Hunyadi [2000]). Ezért óvatosan, de pozitívan fogalmazunk, amikor azt állítjuk, hogy statisztikai eredményeink nem cáfolják meg, inkább támogatják hipotézisünket. A vizsgált 490 tranzakció alapján úgy tünik, a hipotézisünkben megfogalmazott összefüggés létezik, azaz a hosszabb távú kapcsolatokban a partnerek észlelt megbízhatósága függ attól, hogy a kapcsolatban zajló interakció egyes lépései, tranzakciói során a felek milyen várakozással vannak egymás iránt, és ténylegesen mit tapasztalnak. A modell alacsony $R^{2}$ értéke azt is megmutatja ugyanakkor, hogy e két tényezön kívül más faktorok is befolyásolják a bizalomra méltóság észlelt szintjének változását.

Megítélésünk szerint az összefüggés alacsony szintjét az is magyarázhatja, hogy a játékosok által jelzett megbízhatóság szintjei igen kis mértékben ingadoztak, a valamivel nagyobb kilengések csak a játék utolsó köreiben jelentkeztek, de az állományváltozóként értelmezett megbízhatóság változásai itt sem voltak igazán nagyok. A megbízhatóság változása tehát mintánkban közel konstans, s ez azt jelenti, hogy a magyarázó változók együtthatói is nulla közeliek lesznek. Mivel a megbízhatóság változásainak szórásnégyzetei közel nulla körüli értékek, ezért az osztáskor a korrelációs együtthatók sem értelmezhetők jól. A lineáris regressziós modell így nem tünik alkalmasnak arra, hogy hipotézisünket alátámassza. Ugyanakkor, mivel a vizsgált adatsorunk közel konstans, más, akár nem lineáris regresszió sem vezethet magasabb $R^{2}$-re. 
A két - $A$ és $B$ - játékosra végzett regressziós számítások $R^{2}$ értékei kicsit különböznek egymástól. Ez az eredményünk fakadhat a játék azon sajátosságából, hogy a 10 kör során az átadható összegek kumulálódtak. Ez azt jelenteti, a körök döntő többségében $A$ és $B$ játékos szerepei (ki a bizalmat adó és ki a bizalmat kapó fél) összecsúsztak, s csak az utolsó körben állt elő a klasszikus egykörös bizalomjáték alaphelyzete, miszerint $A$ van a bizalmat adó, míg $B$ a bizalmat kapó pozíciójában.

Mindkét játékos regressziós modelljei esetében a visszavárt összeg együtthatója negatív. Ez arra utal, hogy a várakozások negatívan hatottak, valószínúleg az azzal kapcsolatos csalódás miatt. Bár összességében a visszavárt összegre vonatkozó várakozások és a ténylegesen visszakapott összegek nagyon nem különböztek egymástól, amikor viszont eltérés volt, az negatív hatást gyakorolt.

\section{5. Összefoglalás}

Tanulmányunk a bizalomjáték egy általunk kifejlesztett változatát tárgyalta, melyet annak érdekében dolgoztunk ki, hogy tesztelni tudjuk hipotézisünket, mely szerint a játékban a párokat alkotó személyek egymás iránt érzett megbízhatóságának szintjét befolyásolják az adott kapcsolatban zajló tényleges események (mekkora összeget kap az adott játékos), és az azzal kapcsolatos várakozásaik is. Ebben a módosított bizalomjátékban a játékelméleti fogalmak, azaz a bizalom és a bizalomra méltóság mellett megjelent a megbízhatóság koncepciója is, mely az adott játékos észlelése, várakozása azzal kapcsolatban, hogy a jövőben, azaz a következő tranzakció során partnere mennyire fog majd bizalomra méltóan viselkedni. A hagyományos bizalom és bizalomra méltóság folyamatjellegü kategória, mely a partnerek tényleges cselekvéseiben nyilvánul meg. A megbízhatóság viszont állományjellegü, ami az adott kapcsolatban a felek között, azok korábbi történetébe ágyazottan jelenik meg. Munkánk egyik újdonsága, hogy megkülönböztettük ezt a bizalmi jelenségekhez kapcsolódó három (bizalom, bizalomra méltóság, megbízhatóság) koncepciót, és azok mindegyikének mérését be is építettük a játékba.

A tárgyalt módosított ismételt bizalomjáték egyedisége abban is megjelenik, hogy a játék 10 körét összekapcsoltuk oly módon, hogy az átadható összegeket a körök során kumuláltuk. Megítélésünk szerint jobban modellezi a valós kapcsolatok belső dinamikáját az, ha nem ugyanazoknak az egyszerü tranzakcióknak az ismétlése zajlik.

Alapvető célunk annak jobb megértése volt, hogy az állományjellegü megbízhatóság alakulását mivel magyarázhatjuk. Hipotézisünk szerint ezt befolyásolja mind a felek között átadott összegek tényleges nagysága, mind az azokra vonatkozó várakozások. Ez a feltevés a megbízhatóság alakulását egyfajta befektetési folyamat eredményeként 
értelmezi, a felek valós bizalomra méltó cselekvése, azaz az opportunizmus hiánya, és az ezzel járó lemondás bizonyos pénzösszegekről azzal a hozadékkal jár, hogy nő az adott játékos bizalmi készlete, azaz megbízhatósága. Eredményeink nem cáfolják ezt a feltételezést, az említett két tényező mellett ugyanakkor további tényezők is szerepet játszanak a megbízhatóság alakulásában. Ezek azonosítása újabb kutatásokat igényel.

Eredményeink szerint a tranzakciókban kapott összegek és az azokkal kapcsolatos várakozások egyaránt hatnak a partner észlelt megbízhatóságára. Azt ugyanakkor még nem vizsgáltuk, hogy ez milyen módon fejti ki hatását. A szolgáltatásmenedzsment irodalmában a várakozásoknak és azok beteljesülésének kutatása jelentős múltra tekint vissza. E kutatómunka egyik eredménye az elégedettség koncepciója (Parasuraman-Berry-Zeithaml [1991]). Elégedettség akkor alakul ki, ha a várakozások egy adott szituációban teljesülnek, vagy azokat pozitívan túlszárnyaló módon valósulnak meg. Amennyiben az események nem érik el a várakozási szintet, akkor elégedetlenség alakul ki. Eredményeink arra utalnak, hogy az elégedettség koncepciója és hatásmechanizmusa a bizalom jelenségére is igaz lehet. Ennek jövőbeni tesztelését fontosnak tartjuk.

\section{Függelék}

\section{A tárgyalt ismételt bizalomjáték tájékoztatója}

Játékosazonosító: pl.: A1 (azaz kezdő játékos az 1. számú párban)

Tisztelt Játékos!

Üdvözöljük az ún. bizalomjáték résztvevőjeként! Kérjük, figyelmesen olvassa el az alábbi útmutatót! Amennyiben bármilyen kérdése lenne, kérjük, semmiképpen ne kérdezze meg hangosan, hanem KÉZFELTARTÁSSAL jelezze, hogy tisztázni szeretne valamit! Négyszemközt megbeszéljük a kérdését.

Kérjük, hogy mostantól a játék végéig, már ne beszélgessen társaival! E szabály betartása a játék során szerzett eredmény kifizetésének feltétele.

A játék 10 körből áll, egy-egy kör pedig több lépésböl. Egy fordulóban két személy játszik. Az ún. befektető (,A” jelü) játékos abban különbözik társától, hogy ő a játék elején rendelkezik 10 ECU-val (experiment currency unit, azaz kísérleti valuta), és ez a játékos hozza az első befektetési döntést. A partner, az ún. kamatoztató („B” jelü) játékos. Ö az, aki a játék megkezdésekor nem rendelkezik ECU-val, de ő minden körben képes a számára $A$ által átadott aktuális összeget kamatoztatni. Ennek mértékét az ún. kifizetőfüggvény határozza meg. Esetünkben a kamatoztató $(B)$ játékos az adott körben a befektetőtől $(A)$ kapott összeget automatikusan megháromszorozza $(x 3)$. Azt, hogy ki melyik játékos lesz, véletlenszerüen került meghatározásra. Ön a játékban a ...................... játékos!

A játék során nem derül ki, kik alkotnak egy párt, s ezt az információt később is bizalmasan kezeljük. Mindenki egy alkalommal vehet részt a játékban, egy fordulót játszhat. Kérjük, ezt jelen 
ismertető végén nevük, Neptun-kódjuk feltüntetése mellett aláírásukkal erősítsék meg! (Ez elengedhetetlen a résztvevők díjazásához!)

Mint említettük, egy kör több technikai lépésből áll, de minden kör egyetlen döntést tartalmaz. Mindkét játékosnak azt kell eldönteni, hogy az egyes körök elején rendelkezésére álló összegből mennyit adjon át partnerének. Kérjük, figyeljen arra, hogy az átadható összeg felső korlátja mindig az összes rendelkezésre álló pénzmennyiség! A program a körök elején, az átadásra rendelkezésre álló maximális összegeket automatikusan számolja és jelzi majd Önnek. E döntés mellett a többi lépés a játék szempontjából fontos jellemzőknek és információknak az egyszerü rögzítését jelenti.

A játékban való részvételért minden játékos díjazást kap, mégpedig az alábbiak szerint:

Mindenki kap egy 500 Ft-os alapdíjazást. 500 Ft jár pluszban a győztesnek (annak a játékosnak, akinek a játék utolsó körében több pénze lesz, mint partnerének). 2000 Ft-ot pedig arányosítva egyenlően osztunk szét a játék során a két fél között. Az arányosítás a pár, tehát a két játékos által közösen elért összeg és az elméletileg elérhető maximális összeg* hányadosa szerint történik. Minden játékos számára a kifizethető maximum így $2000 \mathrm{Ft}$.

(*10 körös játékunk végén gyüjthető maximális $\mathrm{ECU}=i * 3 k$, ahol $i$ az induló pénzmennyiség, $k$ a körök száma, esetünkben $i=k=10$.)

Kérjük, a program segítségével 10 körön keresztül, lépésről lépésre adja meg a program által kért válaszokat, rögzítse az adatokat!

Kezdődjön a játék! Kérjük, nyissa meg a T: Ibiz-jatek mappában a jatekos_azonosító lap tetején, pl. Jatekos_A1 file-t!

Az első lépést a B játékosnak kell megtennie!

Az alábbi üzenet jelzi a játék végét. Ekkor töltse ki az alábbi nyilatkozatot és jelezzen a játék vezetőjének!

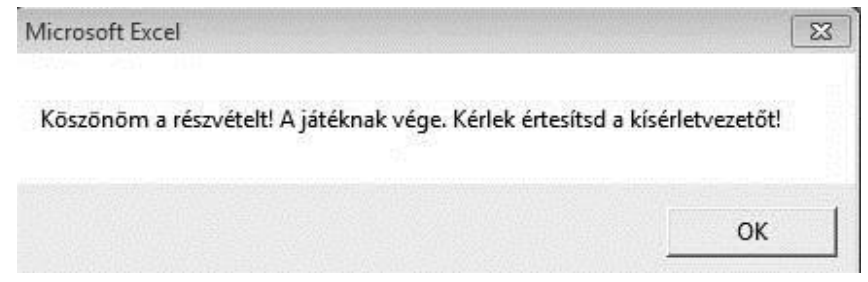

Eredménye:

ECU

Én, (név) (Neptun-kód) aláírásommal igazolom, hogy a BCE Vállalatgazdaságtan Intézetének munkatársai által szervezett bizalomjátékban korábban még nem vettem részt.

Budapest,

Aláírás

Töltse ki a záró kérdőívet!

Játékvezető aláírása

E tájékoztató megfelelően kitöltött és aláírt példányával most már át tudja venni a játék során nyert összeget!

Statisztikai Szemle, 96. évfolụam 8-9. szám 769-793. oldal 


\section{Irodalom}

Ashraf, N. - Bohnet, I. - Piankov, N. [2006]: Decomposing trust and trustworthiness. Experimental Economics. Vol. 9. Issue 3. pp. 193-208. http://dx.doi.org/10.1007/s10683-006-9122-4

BARNEY, J. - HANSEN, M. [1994]: Trustworthiness as a source of competitive advantage. Strategic Management Journal. Vol. 15. Issue S1. pp. 175-190. https://doi.org/10.1002/smj.4250150912

Berg, J. - Dickhaut, J. - MCCABE, K. [1995]: Trust, reciprocity, and social history. Games and Economic Behavior. Vol. 10. Issue 1. pp. 122-142. https://doi.org/10.1006/game.1995.1027

BLomQvist, K. [1997]: The many faces of trust. Scandinavian Journal of Management. Vol. 13. Issue 3. pp. 271-286. http://dx.doi.org/10.1016/S0956-5221(97)84644-1

Boero, R. - Bravo, G. - CAStellani, M. - SQuazzoni, F. [2009]: Reputational cues in repeated trust games. The Journal of Socio-Economics. Vol. 38. Issue 6. pp. 871-877. http://dx.doi.org/ 10.1016/j.socec.2009.05.004

BoHNET, I. - Huck, S. [2004]: Repetition and reputation: implications for trust and trustworthiness when institutions change. The American Economic Review. Vol. 94. Issue 2. pp. 362-366. http://dx.doi.org/10.1257/0002828041301506

Bolton, G. E. - Ockenfels, A. - Thonemann, U. W. [2012]: Managers and students as newsvendors. Management Science. Vol. 58. Issue 12. pp. 2225-2233. http://dx.doi.org/ $10.1287 / \mathrm{mnsc} .1120 .1550$

CAmerer, C. [2003]: Behavioral Game Theory. Russel Sage Foundation. New York.

Chang, L. J. - Doll, B. B. - van't Wout, M. - Frank, M. J. - SAnfey, A. G. [2010]: Seeing is believing: trustworthiness as a dynamic belief. Cognitive Psychology. Vol. 61. Issue 2. pp. 87105. http://dx.doi.org/10.1016/j.cogpsych.2010.03.001

DAs, T. K. - Teng, B.-S. [2004]: The risk-based view of trust: a conceptual framework. Journal of Business and Psychology. Vol. 19. Issue 1. pp. 85-119. http://dx.doi.org/10.1023/B:JOBU. 0000040274.23551.1b

Ford, D. - GAde, L. E. - HÅkAnsson, H. - SnehotA, I. - WAluszewski, A. [2008]: Analysing Business Interactions. IMP Conference Paper. $24^{\text {th }}$ Annual IMP Conference Proceedings. Uppsala. pp. 1-37.

Chaudhuri, A. - Gangadharan, L. [2007]: An experimental analysis of trust and trustworthiness. Southern Economic Journal. Vol. 73. Issue 4. pp. 959-985. http://dx.doi.org/10.2307/20111937

HÁMORI B. [2004]: Bizalom, jóhírnév és identitás az elektronikus piacokon. Közgazdasági Szemle. LI. évf. Szeptember. 832-848. old.

HÅkANSSON, H. - SNehotA, I. [1989]: No business is an island: the network concept of business strategy. Scandinavian Journal of Management. Vol. 22. Issue 3. pp. 187-200. http://dx.doi.org/10.1016/0956-5221(89)90026-2

Hohenthal, J. - Johanson, J. - Johanson, M. [2014]: Network knowledge and businessrelationship value in the foreign market. International Business Review. Vol. 23. Issue 1. pp. 419. http://dx.doi.org/10.1016/j.ibusrev.2013.08.002

HunYadi L. [2000]: A determinációs együtthatóról. Statisztikai Szemle. 78. évf. 9. sz. 753-765. old.

JAP, S. D. - GANESAN, S. [2000]: Control mechanisms and the relationship life cycle: implications for safeguarding specific investments and developing commitment. Journal of Marketing Research. Vol. 37. pp. 227-245. http://dx.doi.org/10.1509/jmkr.37.2.227.18735 
Johanson, J. - MatTsson, L. G. [2015]: Internationalisation in industrial systems - A network approach. In: Holm, U. - Forsgren, M. - Johanson, J. (eds.): Knowledge, Networks and Power. Palgrave Macmillan. Basingstoke. pp. 111-132. http://dx.doi.org/10.1057/9781137508829

KorCZYNSKI, M. [2000]: The political economy of trust. Journal of Management Studies. Vol. 37. Issue 1. http://dx.doi.org/10.1111/1467-6486.00170

Kumar, N. [1996]: The power of trust in manufacturer - Retailer relationships. Harvard Business Review. Vol. 74. Issue 6. pp. 93-107.

Mayer, R. C. - DAvis, J. H. - Schoorman, F.D. [1995]: An integrative model of organizational trust. Academy of Management Review. Vol. 20. Issue 3. pp. 709-734. http://dx.doi.org/10.5465/amr.1995.9508080335

Morgen, R. M. - HunT, S. D. [1994]: The commitment - Trust theory of relationship marketing. Journal of Marketing. Vol. 58. Issue 3. pp. 20-38. http://dx.doi.org/10.2307/1252308

Ostrom, E. - Walker, J. (eds.) [2003]: Trust and Reciprocity. Russell Sage Foundation. New York.

Parasuraman, A. - Berry, L. L. - Zeithaml, V. A. [1991]: Understanding customer expectations of service. Sloan Management Review. Vol. 32. No. 3. pp. 39-48.

Pilbeam, C. - Alvarez, G. - Wilson, H. [2012]: The governance of supply networks: a systematic literature review. Supply Chain Management: An International Journal. Vol. 17. Issue 4. pp. 358-376. http://dx.doi.org/10.1108/13598541211246512

SAMiEE, S. - WALters, P. G. [2003]: Relationship marketing in an international context: a literature review. International Business Review. Vol. 12. Issue 2. pp. 193-214. http://dx.doi.org/10.1016/S0969-5931(02)00096-3

WANG, Q. - XU, J. - WeITZ, B. [2008]: Creativity in buyer-seller relationships: the role of governance. International Journal of Research in Marketing. Vol. 25. Issue 2. pp. 109-118. http://dx.doi.org/10.1016/j.ijresmar.2007.12.006

WiLliAmSON, O. E. [2007]: A tranzakciós költségek gazdaságtana: a szerződéses kapcsolatok irányítása. Kormányzás, Közpénzügyek, Szabályozás. II. évf. 2. sz. 234-255. old.

\section{Summary}

The paper presents and empirically tests a special repetitive trust game. The game distinguishes three trust-related terms: trust, trustworthiness, and reliability. Both trust and trustworthiness are interpreted as a flow type of concepts that can be captured and investigated through the specific movements and actions made by the partners in the game. Reliability is conceptualized as a stock type phenomenon and reflects the perceived level of the trustor toward his/her partner, the trustee.

The authors' special repetitive trust game consists of ten iterations. Anonymous pairs are created, and the perceived level of reliability is directly measured through 10 rounds of the game. The game is also featured by its cumulative character. It means that through the 10 rounds, the amount of the previous iterations can be reinvested. This game design is used for testing the core hypothesis: the actions of the partners of a pair in the game - and the related level of trust and trustworthiness (flow concepts) - depend on the perceived levels of reliability (stock). 